\title{
SEISMOTECTONICS OF THE INNER TIENSHAN: SUUSAMYR BASIN AND ADJACENT AREAS
}

\section{A.V. Mikolaichuk ${ }^{1}$, Z.A. Kalmetyeva ${ }^{2}$, J.-P. Burg ${ }^{3}$, D. Fossati ${ }^{3,4}$, D.V. Gordeev ${ }^{1}$}

${ }^{1}$ Institute of Geology of NAS, Bishkek, Kyrgyzstan

${ }^{2}$ Central-Asian Institute for Applied Geosciences, Bishkek, Kyrgyzstan

${ }^{3}$ Department of Earth Sciences, ETH, Zurich, Switzerland

${ }^{4}$ Marti Tunnelbau AG, Moosseedorf, Switzerland

ABSTRACT. The Ms=7.3 Suusamyr earthquake of August 19, 1992 occurred in an area reputedly aseismic. Because it was not expected there, this event attracted worldwide attention of researchers in seismology and seismotectonics, but their results have not been included in the most recent seismic zoning map of Kyrgyzstan. New studies of neotectonic structures and focal mechanisms of earthquakes in the Suusamyr area and adjacent areas give reason to revise the established notions about the seismicity of the region. The seismic hazard in Inner Tienshan appears important and $\mathrm{M}_{\max }$ are comparable to those of the Northern and Southern Tienshan, where numerous destructive events were documented in the XIX and XX centuries. For the southern parts of the study area, along Naryn River, where hydroelectric power stations are planned, the new data should be used.

KEYWORDS: neotectonics; active fault; earthquake mechanism; seismic hazard

FUNDING: The research was supported by SNSF (IB7320-110694). 


\title{
СЕЙСМОТЕКТОНИКА ВНУТРЕННЕГО ТЯНЬ-ШАНЯ: СУУСАМЫРСКАЯ ВПАДИНА И ПРИЛЕГАЮЩИЕ ТЕРРИТОРИИ
}

\section{А.В. Миколайчук ${ }^{1}$, 3.А. Кальметьева², Ж.-П. Бург³, Д. Фоссати ${ }^{3,4}$, Д.В. Гордеев ${ }^{1}$}

\author{
${ }^{1}$ Институт геологии НАН, Бишкек, Кыргызстан \\ ${ }^{2}$ Центрально-Азиатский институт прикладных исследований Земли, Бишкек, Кыргызстан \\ ${ }^{3}$ Департамент наук о Земле, Высшая техническая школа, Цюрих, Швейцария \\ ${ }^{4}$ Компания «Marti Tunnelbau AG», Мосзеедорф, Швейцария
}

\begin{abstract}
АНнотАЦИЯ. Суусамырское землетрясение (M=7.3) произошло 19 августа 1992 г. в предположительно асейсмичном районе. Поскольку это событие оказалось неожиданным, оно привлекло внимание исследователей в области сейсмологии и сейсмотектоники всего мира. Однако результаты данных исследований не нашли отражения на последней карте сейсмического районирования Кыргызстана. Новые структурные исследования активных разломов и механизмов очагов землетрясений Суусамырской впадины и прилегающих территорий дают основание пересмотреть сложившиеся представления о сейсмичности региона. Сейсмическая опасность во Внутреннем Тянь-Шане $\left(\mathrm{M}_{\text {мах }}\right)$ представляется сопоставимой с таковыми в Северном и Южном Тянь-Шане, где были зарегистрированы многочисленные разрушительные события XIX и XX века. Полученные данные желательно учитывать на юге изученной территории, где планируется строительство гидроэлектростанций Нарынского каскада.
\end{abstract}

КЛЮчЕВЫЕ СЛОВА: неотектоника; активный разлом; механизм очага землетрясения; сейсмическая опасность

ФИНАНСИРОВАНИЕ: Исследования проведены при поддержке SNSF (IB7320-110694).

\section{INTRODUCTION}

Recorded seismicity of the Kyrgyzstan Tienshan shows epicenters aligned along narrow linear zones striking $\mathrm{N} 060^{\circ}-070^{\circ}$. The coincidence of these earthquake lineaments with major faults of the Tienshan Mountains (Fig. 1, $a, b)$ was recognized as early as the first seismotectonic investigations of the 1970s (e.g., [Djanuzakov et al., 1980]). Large destructive earthquakes are often a shock to the population. If specialists have some knowledge on the likely location of future earthquakes, they are still unable to precisely predict when seismic events may occur. This is the case for the M=7.3 1992 Suusamyr earthquake, which was unexpected by both the inhabitants and the earth scientists because, before this event, multiple arguments had been brought forward to conclude that the internal regions of Tienshan are weakly seismic. In particular, the instrumental records supported the assumption that the Suusamyr valley was seismically safe (Fig. 1, c). Because of this dramatic discrepancy between the prevision and the reality, the Suusamyr earthquake attracted worldwide attention of specialists and triggered much work on seismological aspects (e.g. [Djanuzakov et al., 1997; Mellors et al., 1997]) and surface effects in the epicentral area [Bogachkin et al., 1997; Ghose et al., 1997; Havenith et al., 2000; Su Zongzheng et al., 1999; Ainscoe et al., 2019]. These studies considered seismotectonics and seismicity of the region, but their results have not been included in the most recent seismic zoning map of the Suusamyr area [Abdrakhmatov et al., 2012; Turdukulov, 1996]. This omission can be corrected with information on: (i) data on active faults, (ii) maximal earthquake magnitudes possible on these faults, and (iii) focal mechanisms for earthquakes. This paper addresses these issues.

\section{SEISMOGENIC GEOLOGICAL STRUCTURES}

The Suusamyr region is located to the NE of the TalasFergana sinistral strike-slip fault (Figs. 1 and 2, a) (e.g., [Burtman et al., 1996]). The dextral Suusamyr-Toluk Fault is parallel to the Talas-Fergana Fault; it is associated with the strongest aftershock (M=6.7) of the 1992 event and makes the south-western boundary of the Suusamyr earthquake source zone. Two sinistral EW-striking Suek and North Suek faults border this zone at the north. The dextral Karakol and North Karakol faults are located in the north-western part of the region (Fig. 2, a). The EW-striking Northern Kavak Thrust is the southern boundary of the Suusamyr earthquake source zone (Fig. 2,a).

Paleomagnetic data on Late Paleozoic rocks of Central Tien Shan revealed regional, up to $90^{\circ}$ counterclockwise rotation of upper-crust blocks. This rotation is consistent with sinistral wrenching along the EW-striking fault system and dated as pre-Jurassic. Paleomagnetic data from Jurassic and younger rocks show minor, if any, rotation [Bazhenov et al., 1999]. Such rotations evidence that the Late Paleozoic strike-slip faults in Tienshan were not reactivated during the Early Mesozoic. Structural data bring evidence for some of them being reactivated during the Cenozoic [Bazhenov, Mikolaichuk, 2004; Delvaux et al., 2001; Selander et al., 2012]. Sinistral transtension during Oligocene - Early Miocene led to the formation of intermountain basins, such as the Jumgal (Fig. 2, $a$ ) and Naryn basins (see Fig. 1, $b$ ) and has been inverted to dextral transpression since the Late Pliocene [Morozov et al., 2014]. Dextral movements at a rate of 5-6 mm/year activated the Karakol Fault (Fig. 2, a) over the Late Pleistocene - Holocene period [Makarov et al., 2005]. These observations are consistent with the results of tectonophysical studies. According to the reconstructed 

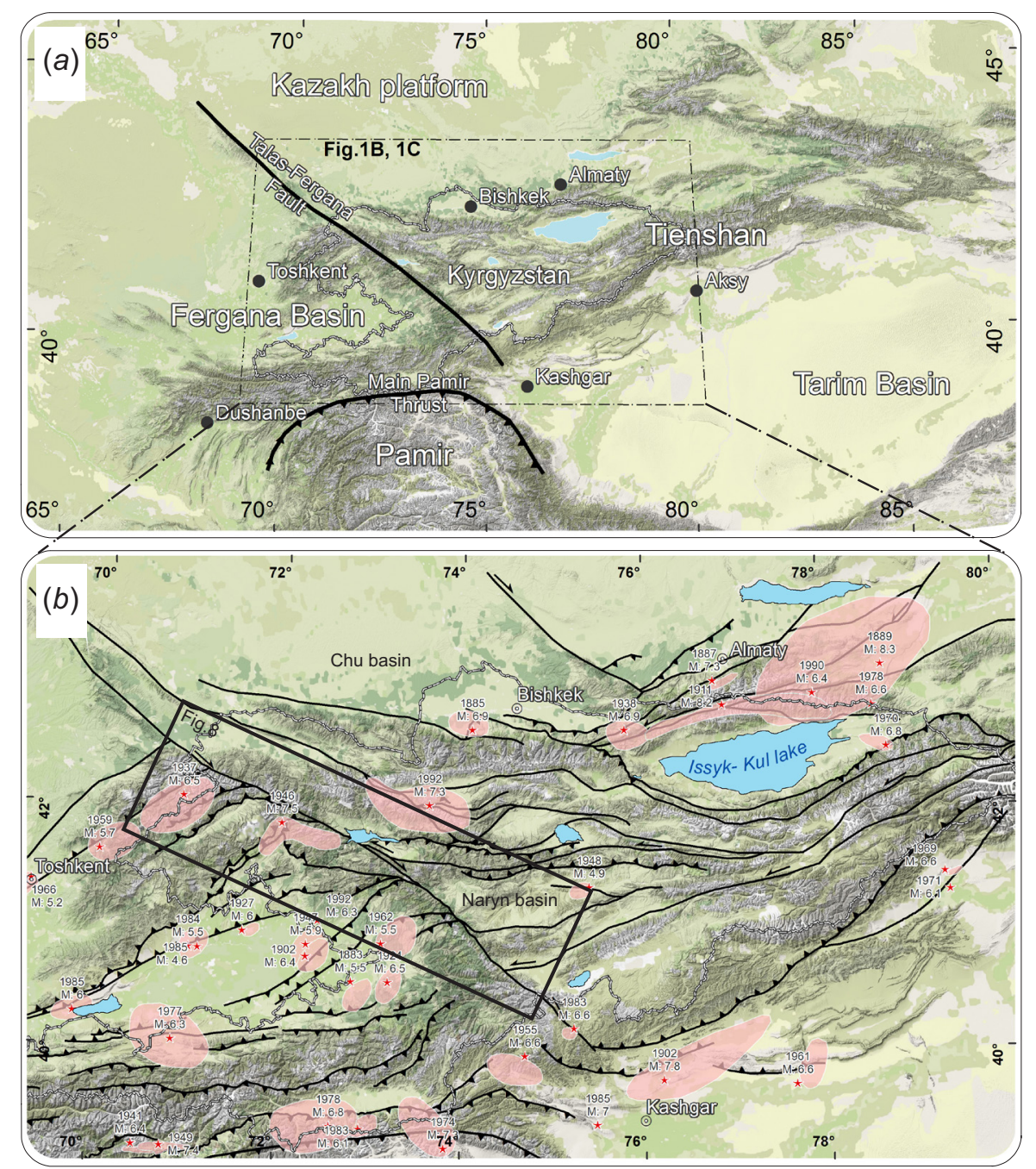

Main quaternary and active faults:
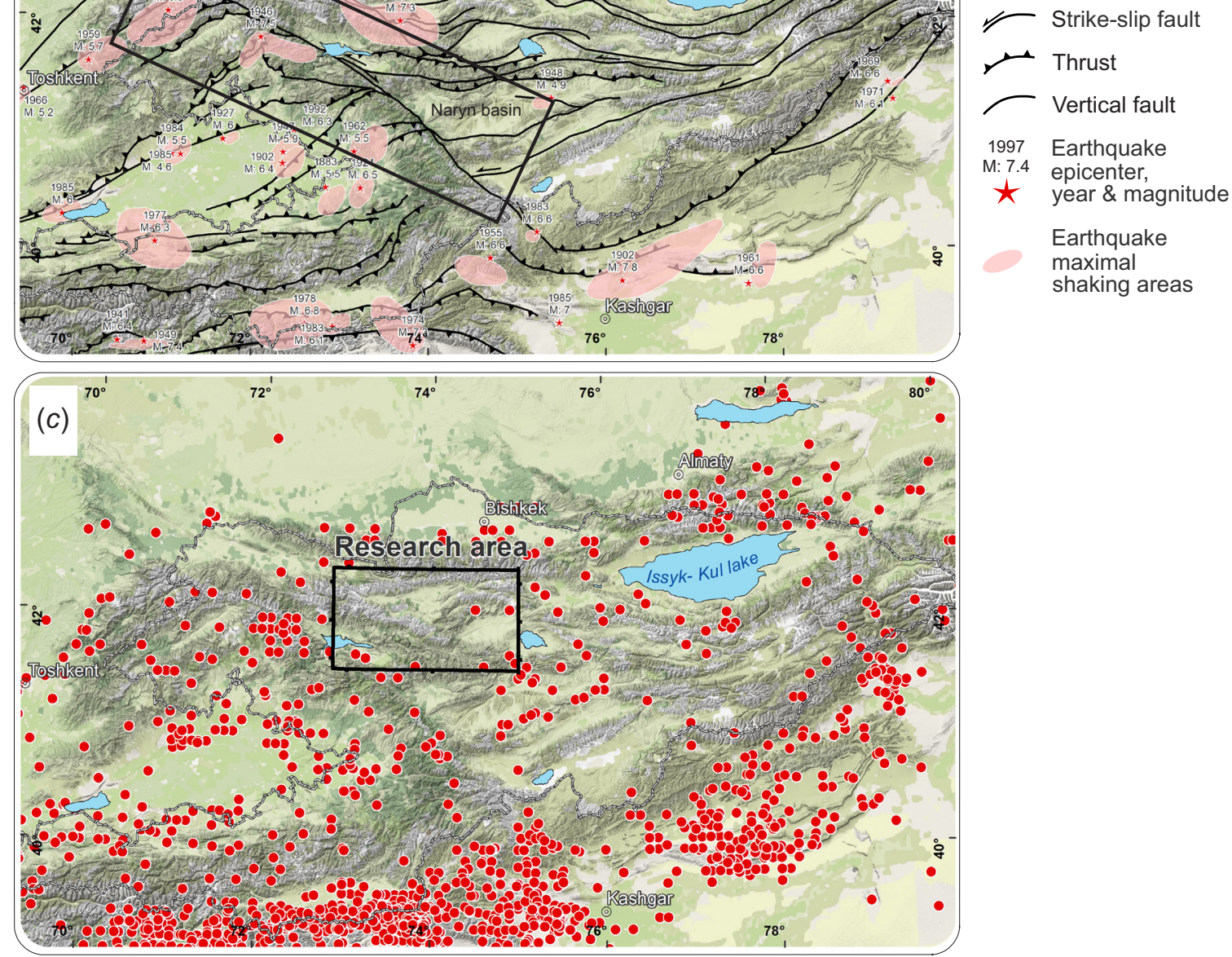

Fig. 1. Overview of seismicity and active faults in the Tienshan: $(a)$ - large scale overview of the study area, TFF - Talas-Fergana Fault; MPT - Main Pamir Thrust; $(b)$ - active faults after [Kalmetieva et al., 2009]; $(c)$ - map of the M $\geq 4.5$ earthquake epicenters from ancient times to August 19, 1992 according to the KIS NAN KR catalogue in the limits of $39.5-43^{\circ} \mathrm{N} \& 70.0-80.0^{\circ} \mathrm{E}$ [Kalmetieva et al., 2009]. Beyond these limits USGS data (http://earthquake.usgs.gov) for the period since 1971 year (till the $1992 \mathrm{M}=7.3 \mathrm{Suusamyr}$ earthquake) were used.

Рис. 1. Обзорные схемы сейсмичности и активных разломов Тянь-Шаня: $(a)$ - обзорная схема района исследования, TFF Таласо-Ферганский разлом; МРТ - Главный Памирский надвиг; (b) - активные разломы по [Kalmetieva et al., 2009]; (c) - карта эпицентров землетрясений $\mathrm{M} \geq 4.5$ с древних времен до 19 августа 1992 г. по каталогу КИС НАН КР (39.5-43 ${ }^{\circ} \mathrm{N}$; 70.0-80.0 $\left.{ }^{\circ} \mathrm{E}\right)$ [Kalmetieva et al., 2009]. Дополнительно использовались данные USGS (http://earthquake.usgs.gov) за период с 1971 г. до момента возникновения Суусамырского землетрясения M=7.3 в 1992 г. 

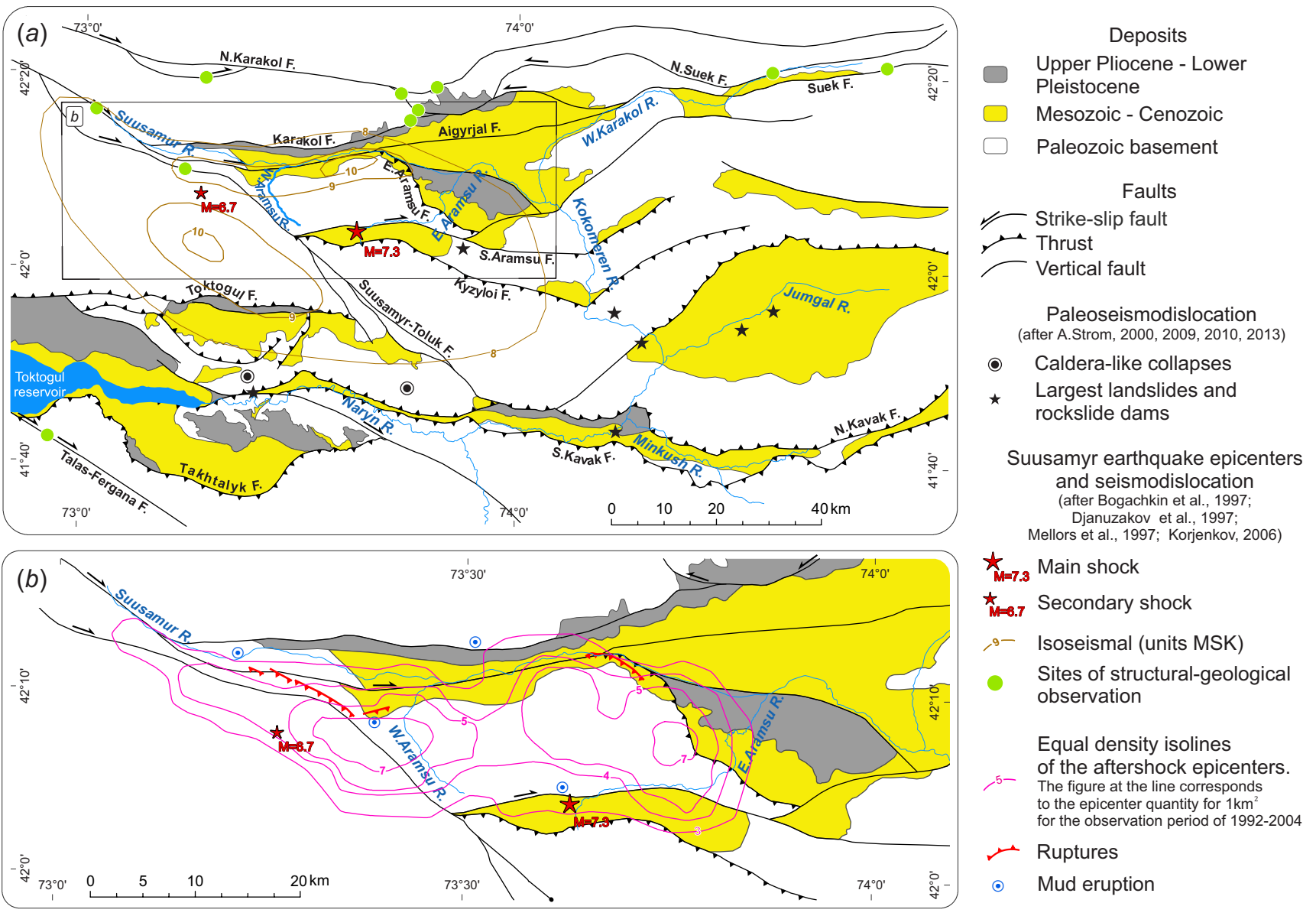

Fig. 2. Neotectonics of the Suusamyr earthquake area $(a)$ and seismotectonic framework of the Suusamyr earthquake source $(b)$.

Рис. 2. Неотектоническая схема района Суусамырского землетрясения $(a)$ и сейсмотектоническая структура очага Суусамырского землетрясения $(b)$.

present-day stress state, the Suusamyr and Kochkor intramountain basins are located in the zone of horizontal shear [Rebetsky et al., 2016].

According to instrumental data, the epicenter of the Suusamyr earthquake is in the heads of the West Aramsu and East Aramsu rivers, which are spatially related to the E-W South-Aramsu strike-slip fault and the Kyzyloi thrust (Fig. $2, a)$. The second, strongest shock came 68 minutes after the main shock on the N-W segment of the Suusamyr-Toluk Fault, where a surface rupture occurred. This rupture could be traced for more than $6 \mathrm{~km}$ lengthwise as a series of imbricate fractures cutting moraines and proluvial cones (Fig. 2, b). In kinematic terms, the rupture plane dipped $<30^{\circ}$ to the southwest and had a $0.9-1.4 \mathrm{~m}$ thrusting displacement with a small $(10-15 \mathrm{~cm})$ dextral component [Bogachkin et al., 1997; Su Zongzheng et al., 1999]. The second seismic disruption appeared $25 \mathrm{~km}$ to the east, at the junction of the Aigyrzhal and East-Aramsu faults (Fig. 2, $a, b)$. It consisted of a $4 \mathrm{~km}$ long series of fractures, the most prominent of which in the flood plain of Suusamyr River, near km 162 of the Bishkek-Osh highway. It was also a thrust with dextral strike-slip component. The largest vertical displacement was $2.7 \mathrm{~m}$ with a horizontal offset of 20-30 cm [Bogachkin et al., 1997; Ghose et al., 1997; Ainscoe et al., 2019].
The area of subsequent events such as landslides, rockslides, rockfalls, mud eruption and soil fracturing amounts to more than $4,000 \mathrm{~km}^{2}$. Mapping of these features, together with the degree of infrastructure damage, formed the basis for the earthquake intensity assessment [Korjenkov, 2006]. Intensity isolines 9 and 10 (MSK64 units) define two separate ellipses elongated along the activated faults (Fig. 2, a), one for the main shock along the E-W Aigyrdjal Fault, the other for the second shock along the NW-SE Suusamyr-Toluk Fault. Westward propagation of the seismic rupture along the Suusamyr-Toluk Fault was inferred from the aftershock migration direction [Djanuzakov et al., 2003; Korjenkov, 2006]. As both rupture zones have thrust and dextral strike-slip components, the double shock induced a counterclockwise rotation of the Aramsu Block (Fig. 2, b). This interpretation was already stated after primary investigations of the source area of the Suusamyr earthquake [Bogachkin et al., 1997]. The highest density of aftershocks was recorded within this Aramsu block. Mud eruptions shortly after the seismic event along the borders of this block are consistent with the block rotations and subsequent openings of favorably oriented fracture zones (Fig. 2, b).

By dating paleoseismic dislocations in the epicentral zone of the Suusamyr earthquake, it was established that catastrophic earthquakes comparable to the 1992 event 


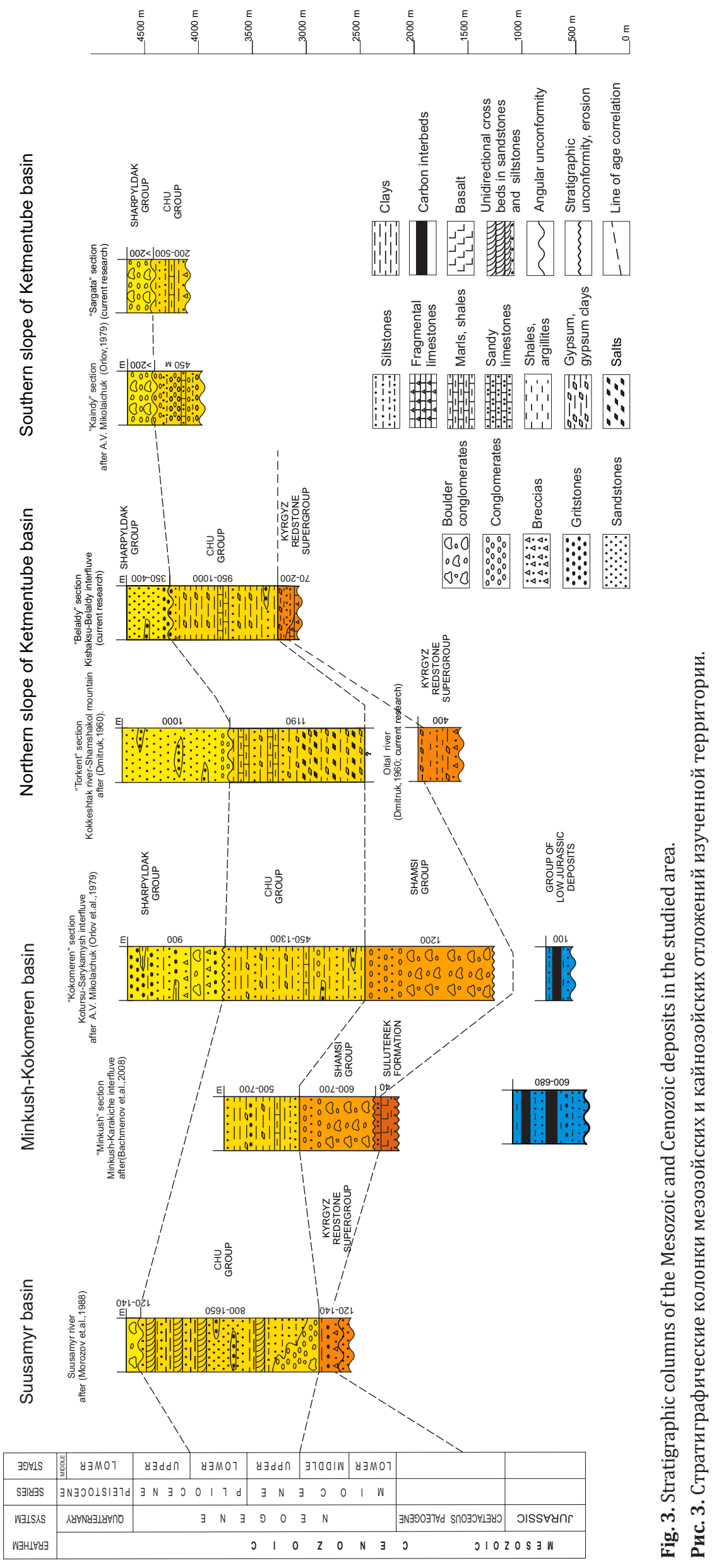


occur at an interval of 3-5 ka [Ainscoe et al., 2019]. These data, along with the decoding of the neotectonic structure of the area and information about the present-day stress field [Rebetsky et al., 2016] probably are sufficient to create a tectonophysical model of the earthquake source based on the dextral rotation of the Aramsu block.

Structures in the area to the south of the Suusamyr earthquake source zone are completely different. The EW-striking conjugated Northern Kavak and Southern Kavak Thrusts brought Paleozoic rock units on the up to 3500-4000 m thick Jurassic to Cenozoic sediments of the Minkush-Kokomeren depression [Bachmanov et al., 2008; Sadybakasov, 1990] (Fig. 3), the stratigraphy of which is similar to that of the main basins, such as the Chu, Issykul and Naryn Basins of Central Tien Shan (see Fig. $1 b$ ). The Northern Kavak and Southern Kavak Faults join near the eastern end of the Tokotgul reservoir, and the westward continuation of the Minkush-Kokomeren depression is a suture [Burg, Mikolaichuk, 2009; Mikolaichuk et al., 2008]. The Minkush-Kokomeren depression formed during Late Pliocene - Pleistocene transpression with shortening (evidenced by folds, reverse and thrust faults) combined with sinistral strikeslip offsets [Bachmanov et al., 2008].

\section{MICROSTRUCTURE - FAULT DATA}

The structural work consisted in a systematic investigation of outcrops exposing mapped faults to determine relative movements from fault surface structures such as striations and sense of shear criteria. Striae are mostly minerals fibres, ridges and grooves produced by hard objects driven along the fault surface (Fig. 4). Local senses of shear were defined from steps, calcite fibre growth, Riedel shears and half-moon features (e.g. [Twiss and Moore, 1992]). All fault planes were very sharp. Those are features characterizing brittle faults formed under very low temperatures near surface conditions. Taking into consideration this observation and working on or close to active faults with locally documented surface ruptures, we assumed that measured striae and movement features recorded recent movements. More than 12 mesoscopic fault planes with attitudes as various as possible were measured in all sites, which are few tens of metres long and usually of uniform lithology. Such field precautions are required to allow a reliable kinematic analysis.

Fault data were systematically recorded with the aim of computer-aided paleostress tensor calculations. We used the Program FSA 28.3 [Célérier, 2009], which is based on a Monte Carlo search calculation, using random stress tensors to evaluate the tensor best-fitting the measured fault planes and their striations. The detailed assumptions and working procedure are described in [Burg et al., 2005] and further developed in [Célérier et al., 2012]. The best-fitting solution is a reduced stress tensor that can be graphically visualized as stereographic, lower projection of fault data and calculated principal stress. Robustness of the result can be checked with Mohr circles of calculated states of stress and histograms of angular error [Burg et al. 2005]. Since such calculations were aimed at supporting instrumental, seismic information from focal mechanism, we will not develop further this routine technique of structural geology (e.g. [Angelier, 1994; Twiss Unruh, 1998]). At variance with seismological information, it is accepted that such calculations provide a longer term assessment of 'stress' directions than the instrumental time.

The results are summarized as stereographic, lower hemisphere projections of principal stress directions and the shape ratio of the corresponding stress ellipsoid $r=\left(\sigma_{1}-\sigma_{2}\right) /$ $\left(\sigma_{1}-\sigma_{3}\right)$, where $\sigma_{1^{3}} \sigma_{2} \geq \sigma_{3}$, all positive in compression. $\mathrm{r} \gg 0$ means that $\sigma_{1} \gg \sigma_{2}, \mathrm{r} \approx 1$ if $\sigma_{2} \gg \sigma_{3}$. The latter case concerns the two easternmost sites, all other calculated tensors being $>0.7$ (Fig. 5). Altogether, these values indicate that principal stresses have magnitudes very close to each other, which can be expected for near-surface faulting and which makes easy swaps between $\sigma_{1}$ and $\sigma_{2}$ or $\sigma_{2}$ and $\sigma_{3}$, thus a variable stress field combining compression and extensionregimes. Only two sites (Muztor River and Suusamyr 1.3) yielded 'Andersonian' states of stress, with one of the principal stress nearly vertical. However, horizontal $\sigma_{1}$ in Muztor River indicates compression, while subvertical $\sigma_{1}$
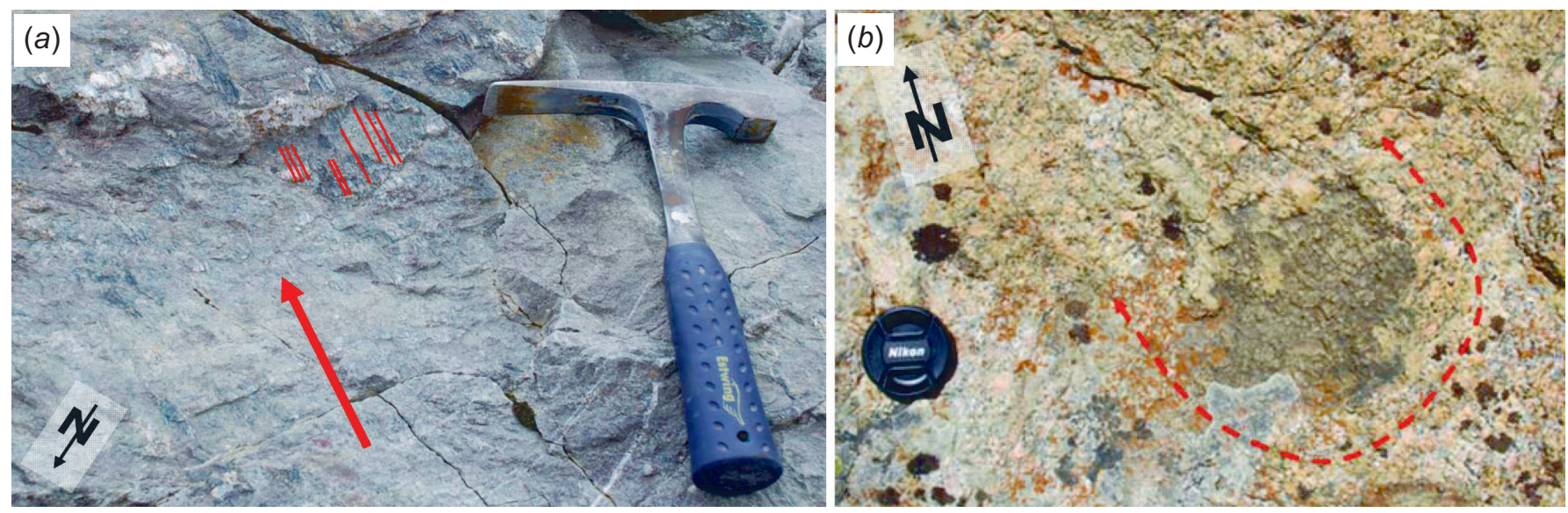

Fig. 4. Examples of fault plane features used for kinematic analysis: $(a)$ - slickensides on a granitic rock near from Karakol Pass; (b) - half-moon shaped Riedels from SW Tuyashuu Pass.

Рис. 4. Примеры плоскостных характеристик разлома, использованных для кинематического анализа: $(a)$ - зеркала скольжения в гранитах вблизи перевала Каракол; $(b)$ - трещины Риделя в форме полумесяца к юго-западу от перевала Туяшуу. 


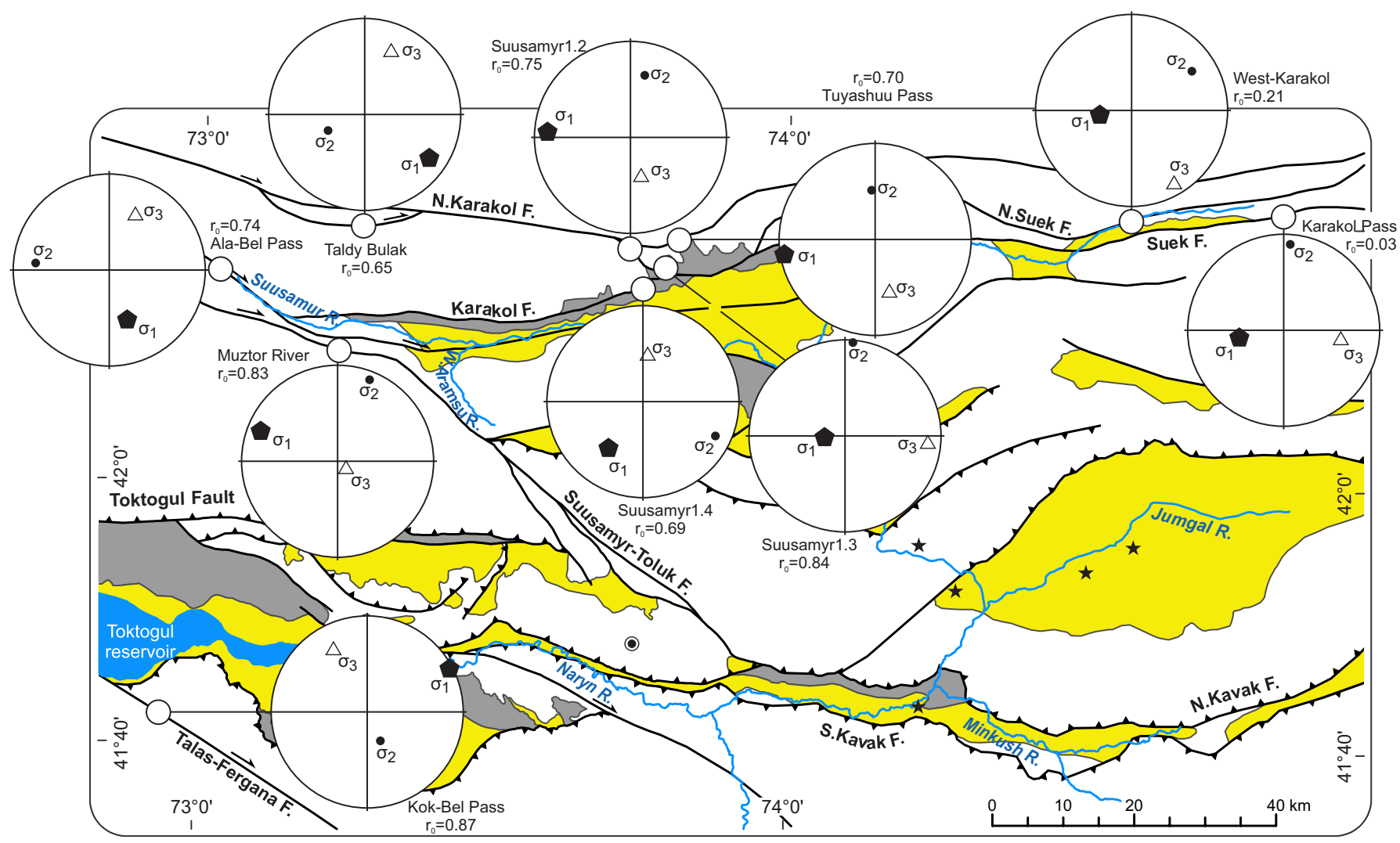

Fig. 5. Site positioned, and determined for them lower hemisphere stereographic projections of paleostress orientations calculated from the kinematic fault analysis and the shape ratio. The method summarized in text.

Рис. 5. Местоположение сайтов и определенные для них стереографические проекции главных осей палеонапряжений в нижней полусфере, рассчитанные на основе кинематического анализа разломов, и коэффициенты Лоде - Надаи. Суть метода изложена в тексте.

in Suusamyr 1.3 indicates extension. All other calculated tensors yielded inclined principal stress directions, most of them with a rather, yet ill-defined WSW-ENE compression. Two reasons are envisioned to explain this variability in the orientation and the shape ratio of the calculated tensor. (1) Measured fault planes were reactivate while stresses vary or the rock mass rotates so that each fault datum records a different stress tensor relative to its reference frame; (2) Measured fault planes were reactivated under a stable configuration of stress and rock mass orientation, but local reactivation matching local heterogeneities yields a regionally imperfect solution. Since in most tensors, none of the principal axes is either vertical or horizontal, a most likely hypothesis is tilting due to block rotations after faulting, possibly linked to free topographic effects.

The complexity of the results may also reflect the fact that measurements lump fault information related to major faulting events, which are responses to regionally significant stress fields, with fault data recording 'aftershock' events, which relax local stresses and deformation. Comparison with modern seismicity suggests that calculated tensors like focal mechanisms document movements responding to local post-seismic relaxation of stresses along different faults under possibly different states of stress. Calculations are therefore significant in interpreting long-term accumulation of stresses and strain in the deforming upper crust.

\section{MOTION TYPES IN THE EARTHQUAKE SOURCES}

The existing network of seismic stations allows comparing the types of motion at the earthquake source with the movements from fault surface structures. There was no seismic event in the 20 years preceding the Ms=7.3 Suusamyr earthquake in its source area. For this reason, we could only use the fault plane solutions for the main shock and the aftershocks recorded by the Kyrgyz analogue network. The aftershock solutions within the first five hours after the main shock are not defined because of record overlays. The Suusamyr main shock is consistent with structural observations, i.e. reverse with a dextral component (Fig. 6). Focal mechanisms of $\mathrm{M} \geq 4$ aftershocks vary regionally. In the southern part of the aftershock area, the thrust component is similar to the motion of the main shock. To the north, thrust movements that occurred on shallower dipping planes whilst strike-slip components are important. Normal faulting took place in the peripheral part of the aftershock area. Several normal faults are located to the north-west of the main $M=6.7$ aftershock, and others at the south-eastern edge of the aftershock area (Fig. 6).

These solutions correlate well with the variety of motions and stress tensor calculations defined from microstructural studies, for example, for the Tuyashuu Pass, Alabel Pass and Karakol. However, thrusting is the prevailing motion of active faults of the Suusamyr earthquake source 


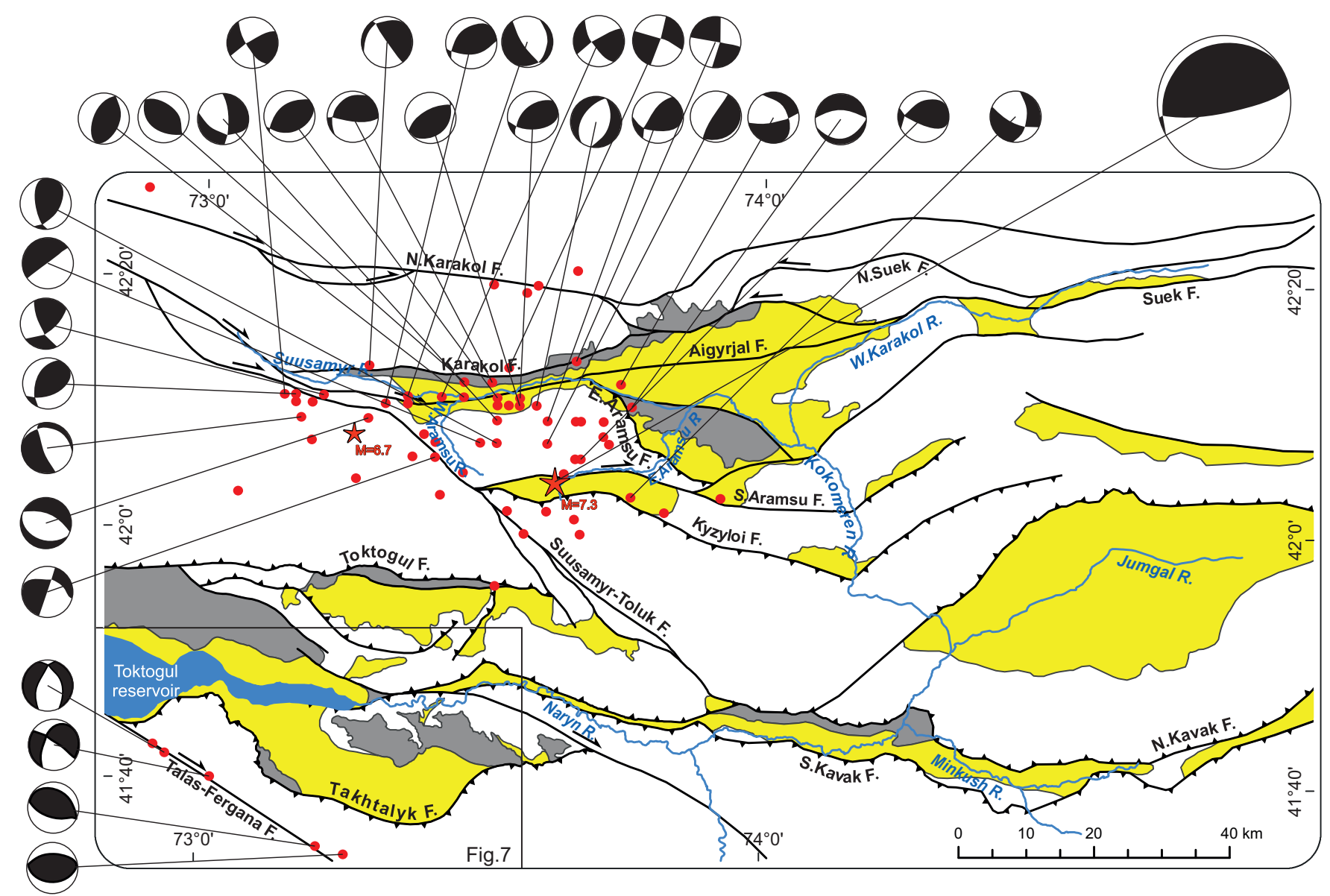

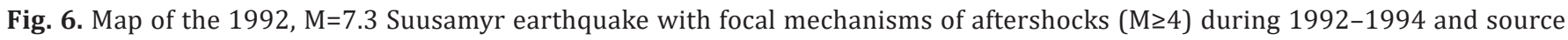
mechanisms for weaker seismic events $(\mathrm{M}=3.3)$ of the Talas-Fergana fault area during the 1992-2007 period. According to 'Earthquakes of Northern Eurasia', Yearbook, 1992-2007. Compressional quadrants are shaded.

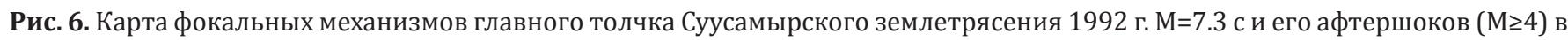
течение 1992-1994 гг., а также механизмов очагов более слабых сейсмических событий (M=3.3) в зоне Таласо-Ферганского разлома за 1992-2007 гг. (по данным ежегодника «Землетрясения Северной Евразии», 1992-2007). Области сжатия закрашены.

area. Earthquakes to the south of the Suusamyr earthquake epicenter were not strong $(M<4.5)$. Only 4 earthquakes with M>4 were recorded in the last 15 years along the middle segment of the Talas-Fergana Fault (Fig. 7). Their focal mechanisms (two of them are normal faults, and two are thrusts) yield no prevailing motion type. Again, this difference in stress regimes matches microstructural calculations, normal faults likely accommodating local tension, for example in releasing bends in the general transpressional tectonic system under a sub-spherical stress tensor. To complement information of so few earthquakes, the fault plane solutions of events with $\mathrm{M}<3.5$ (Fig. 7) have also been considered in 'Earthquakes of Northern Eurasia', Yearbook, 1992-2007. There are 7 strike-slip, 5 thrust and 3 normal fault events. This suggests prevalence of strikeslip motion along the Talas-Fergana Fault segment traced on the map (Fig. 7).

\section{MAXIMAL MAGNITUDE OF THE EARTHQUAKES}

Historical and instrumental data provide no record of any ancient earthquake comparable in magnitude with the 1992 Suusamyr earthquake in the study area over the last
200-300 years (see Fig. 1, c). This period, however, is very short compared to the recurrence intervals of large intraplate earthquakes, which usually range from several centuries to several millennia [Djanuzakov et al., 1980, 1997]. That is why more reliable $\mathrm{M}_{\max }$ estimates require using paleoseismologic data [McCalpin, 1996, 2009; Solonenko, 1974; Yeats et al, 1997]. Paleoseismologic studies in the study area identified numerous surface ruptures, large rockslides and caldera-like cavities associated with large prehistoric earthquakes [Strom, 2000, 2009, 2013; Korjenkov, 2006; Korjenkov et al. 2012; Mamyrov et al. 2009]. The largest possible $M_{\max }$ $M=7.3$ for the South-Aramsu and M=6.9 for the SuusamyrToluk Faults (see Fig. 2, $a$ ) were estimated in accordance with the magnitudes of the main shock and largest aftershock of the Suusamyr earthquake. The $\mathrm{M}_{\max }$ for the Kyzyloi thrust was estimated from the Late Pleistocene Kokomeren rockslide, which is located in the western part of the fault and is one of the biggest paleoseismologic events in Kyrgyzstan [Strom, Stepanchikova, 2008; Strom, 2010]. This gigantic rockslide $\left(41.93^{\circ} \mathrm{N}, 74.23^{\circ} \mathrm{E}\right)$ is approximately $1.0 \mathrm{~km}^{3}$. The 400 -m thick rockslide is exposed on the left bank of Kokomeren River, where it covers a high fluvial terrace 


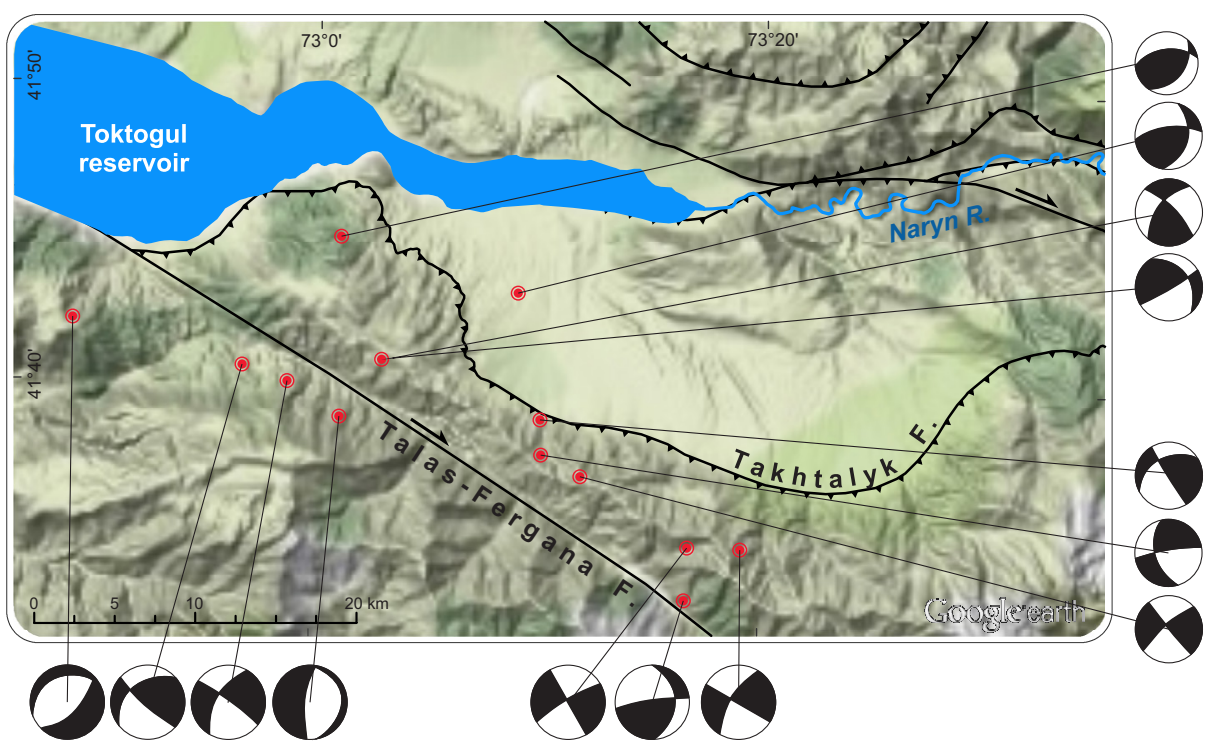

Fig. 7. Focal mechanisms of weak $(M<3.3)$ seismic events along the Talas-Fergana fault during the 1992-2007 period, using Earthquakes of Northern Eurasia, Yearbook, 1992-2007.

Рис. 7. Фокальные механизмы слабых (M<3.3) сейсмических событий вдоль Таласо-Ферганского разлома за период 19922007 гг. по данным ежегодника «Землетрясения Северной Евразии», 1992-2007.

that was about $100 \mathrm{~m}$ above the riverbed at the time of the rockslide. The most important indication in favour of seismically-triggered landslide is the presence of an active fault that displaced the river terraces few hundred meters downstream from the site [Strom, Stepanchikova, 2008]. According to its morphological parameters, this landslide is bigger than all the known surface damages caused by the Suusamyr earthquake. Consequently, the $\mathrm{M}_{\max }$ value along the Kyzyloi Fault is likely $>7.3$.

The $\mathrm{M}_{\max }$ of the Talas-Fergana Fault is taken from the Chatkal earthquake (1946; M=7.5, I0=9-10 of MSK64) [Djanuzakov et al., 2003]. Moreover, the earthquake source zone with $\mathrm{M}=7.1-8$ is aligned along the Talas-Fergana Fault [Abdrakhmatov et al, 2012; Djanuzakov et al., 1980].

This zone is based on 17 seismic events documented between $6120 \pm 170$ and $250 \pm 50$ years, with an average return period of 300 years [Korjenkov et al. 2012; Mamyrov et al., 2009]. These events were dated by the radiocarbon method (Table; Fig. 8). Traces of the largest events allow concluding that $\mathrm{M}_{\max }$ for these events might reach 8 units [Abdrakhmatov et al., 2012; Djanuzakov et al., 1980].

One paleoseismic evidence is the $234 \mathrm{~m}$ deep landslidedammed Sarychelek Lake in the upper reaches of the West Karasy River valley (41⒌ 51 'N, $\left.71^{\circ} 59^{\prime} \mathrm{E}\right)$. It was formed

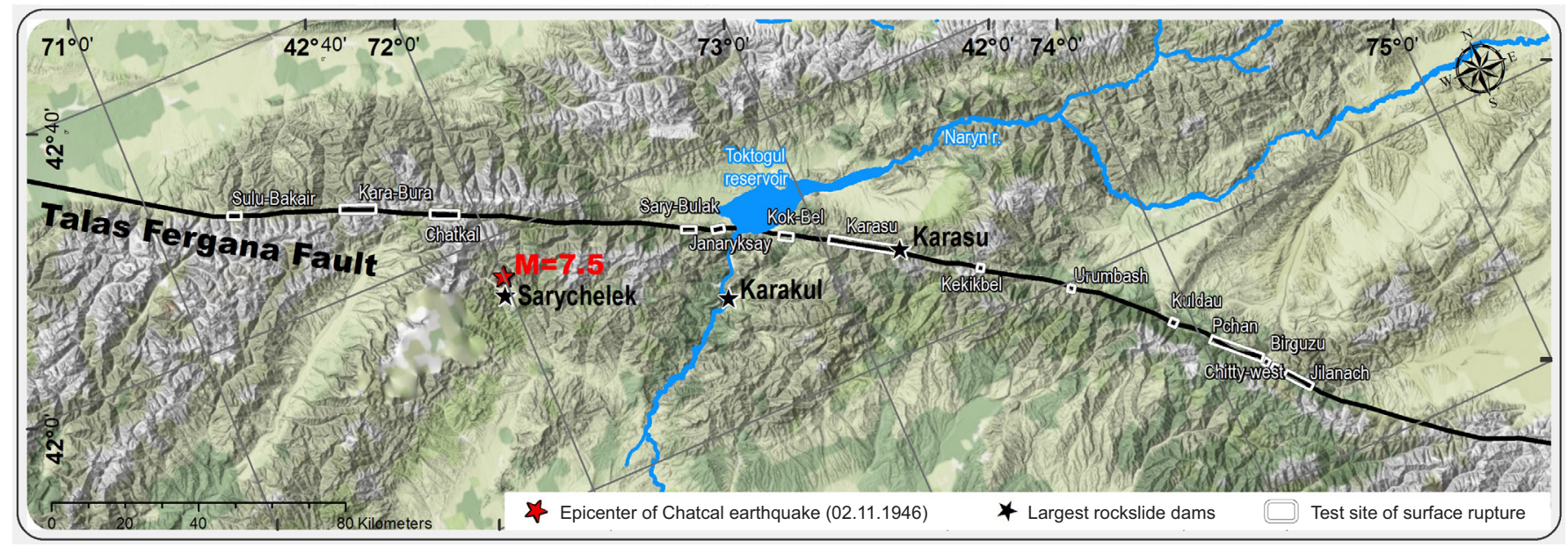

Fig. 8. Paleoseismicity along the Talas-Fergana Fault after [Burtman et al., 1996; Korjenkov et al., 2012; Mamyrov et al., 2009; Strom, 2010; Trifonov et al., 1990]. White rectangles are sites where surface rupture were investigated with trenches. Dating for these sites is given in Table.

Рис. 8. Палеосеймодислокации вдоль Таласо-Ферганского разлома по [Burtman et al., 1996; Korjenkov et al., 2012; Mamyrov et al., 2009; Strom, 2010; Trifonov et al., 1990]. Светлые прямоугольники - сегменты разлома, вскрытые траншеями. Датировки по этим участкам приведены в таблице. 


\section{Radiocarbon dates of samples collected from displaced gullies along the Talas-Fergana Fault Радиоуглеродные датировки образцов (палеопочв), отобранных из смещенных русел вдоль Талас-Ферганского разлома}

\begin{tabular}{|c|c|c|c|c|c|}
\hline $\begin{array}{l}\text { River valley or } \\
\text { a name of the fault } \\
\text { segment }\end{array}$ & $\begin{array}{l}\text { Obtained radiocarbon } \\
\text { ages, years }\end{array}$ & $\begin{array}{l}\text { Average age of the } \\
\text { earthquakes, years }\end{array}$ & $\begin{array}{l}\text { River valley or } \\
\text { a name of the fault } \\
\text { segment }\end{array}$ & $\begin{array}{l}\text { Obtained radiocarbon } \\
\text { ages, years }\end{array}$ & $\begin{array}{l}\text { Average age of the } \\
\text { earthquakes, years }\end{array}$ \\
\hline \multirow{5}{*}{ Jilangach } & $1720 \pm 70$ & $1720 \pm 70$ & Kok-Bel & $4900 \pm 230$ & $4900 \pm 230$ \\
\hline & $1940 \pm 50$ & $1940 \pm 50$ & Janaryksay & $1440 \pm 30$ & $1440 \pm 30$ \\
\hline & $2630 \pm 70$ & \multirow{2}{*}{$2685 \pm 70$} & \multirow{9}{*}{ Sary-Bulak } & $440 \pm 45$ & \\
\hline & $2740 \pm 70$ & & & $505 \pm 80$ & $475 \pm 80$ \\
\hline & $3970 \pm 40$ & $3970 \pm 40$ & & $1130 \pm 100$ & $1130 \pm 100$ \\
\hline \multirow{2}{*}{ Chitty-West } & $4590 \pm 100$ & $4590 \pm 100$ & & $2385 \pm 130$ & \multirow{2}{*}{$2400 \pm 130$} \\
\hline & $5800 \pm 1300$ & $5800 \pm 1300$ & & $2415 \pm 100$ & \\
\hline \multirow{2}{*}{ Birguzy } & $3030 \pm 90$ & $3030 \pm 90$ & & $4930 \pm 90$ & $4930 \pm 90$ \\
\hline & $3740 \pm 600$ & $3740 \pm 600$ & & $5200 \pm 140$ & $5220 \pm 150$ \\
\hline \multirow{5}{*}{ Pchan } & $2180 \pm 120$ & $2230 \pm 120$ & & $5240 \pm 150$ & \multirow[b]{2}{*}{$6120 \pm 170$} \\
\hline & $2280 \pm 70$ & \multirow[t]{2}{*}{$2590 \pm 600$} & & $6120 \pm 170$ & \\
\hline & $2540 \pm 70$ & & \multirow{10}{*}{ Chatkal } & $250 \pm 50$ & $250 \pm 50$ \\
\hline & $2640 \pm 600$ & \multirow{2}{*}{$3150 \pm 40$} & & $1150 \pm 40$ & \multirow{3}{*}{$1195 \pm 50$} \\
\hline & $3150 \pm 40$ & & & $1220 \pm 50$ & \\
\hline \multirow{3}{*}{ Kyldau } & $2320 \pm 40$ & $2320 \pm 40$ & & $1220 \pm 50$ & \\
\hline & $3670 \pm 80$ & \multirow{2}{*}{$3670 \pm 80$} & & $1350 \pm 60$ & \multirow{3}{*}{$1385 \pm 60$} \\
\hline & $3670 \pm 80$ & & & $1350 \pm 60$ & \\
\hline Urumbash & $1510 \pm 60$ & $1510 \pm 60$ & & $1450+40$ & \\
\hline Keklikbel & $1240 \pm 60$ & $1240 \pm 60$ & & $5050+50$ & \multirow{3}{*}{$2020 \pm 50$} \\
\hline \multirow{4}{*}{ Karasu } & $285 \pm 35$ & $285 \pm 35$ & & $\begin{array}{l}20<0 \pm 50 \\
2020+50\end{array}$ & \\
\hline & $975 \pm 65$ & \multirow{3}{*}{$990 \pm 75$} & & $2020 \pm 50$ & \\
\hline & $980 \pm 55$ & & \multirow{6}{*}{ Kara-Bura } & $405 \pm 100$ & \\
\hline & $1015 \pm 75$ & & & $460 \pm 40$ & $450 \pm 100$ \\
\hline \multirow{5}{*}{ Kok-Bel } & $240 \pm 50$ & \multirow{3}{*}{$295 \pm 90$} & & $480 \pm 35$ & \\
\hline & $270 \pm 85$ & & & $4465 \pm 130$ & $4465 \pm 130$ \\
\hline & $370 \pm 90$ & & & $5910 \pm 130$ & $5910 \pm 130$ \\
\hline & $2340 \pm 120$ & \multirow{2}{*}{$2435 \pm 120$} & & $6100 \pm 200$ & $6100 \pm 200$ \\
\hline & $2500 \pm 100$ & & Sulu-Bakair & $5210 \pm 155$ & $5210 \pm 155$ \\
\hline
\end{tabular}

Note. Sites (fault segments) are arranged as shown in Fig. 8 from SE to NW. Compiled by [Korjenkov et al., 2012] after [Burtman et al., 1996; Korjenkov et al., 2010; Mamyrov et al., 2009; Trifonov et al., 1990].

Примечание. Участки (сегменты разломов), расположенные в последовательности, показанной на рис. 8, с ЮВ на СЗ. Составлены [Кorjenkov et al., 2012] по [Burtman et al., 1996; Korjenkov et al., 2010; Mamyrov et al., 2009; Trifonov et al., 1990].

by a $34 \mathrm{~km}^{2}$ prehistoric landslide that left the $6.5 \mathrm{~km}$ long headscarp in Devonian sedimentary rock. The dam volume is $>6 \mathrm{~km}^{3}$ [Strom, 2010]. Another paleoseismic evidence is the $300 \times 106 \mathrm{~m}^{3}$ Karakul rockslide that blocked the Karasu-Left River mouth ( $\left.41^{\circ} 38^{\prime} \mathrm{N}, 72^{\circ} 39^{\prime} \mathrm{E}\right)$. The $2.5 \times 108 \mathrm{~m}^{3}$ and about $250 \mathrm{~m}$ high rockslide is composed of Devonian limestone that collapsed from the $900 \mathrm{~m}$ high left bank of the valley and thrusted over Permian sandstone and conglomerates. Besides the Karasu-Left River mouth, it blocked also the Naryn River [Strom, 2010]. The resulting 150 m deep Karasu Lake invaded the Karasu-Left River valley. This dam is located at $41^{\circ} 34.5^{\prime} \mathrm{N}, 73^{\circ} 13.5^{\prime} \mathrm{E}$ exactly over the trace of the Talas-Fergana active fault [Mamyrov et al., 2009; Strom, 2010]. Comparable paleoseismological events occurred along the Northern-Kavak Fault, as evidenced by a series of caldera-like craters and rockslides (see Fig. 2, a). The eastern crater (Kyzylkul, $41^{\circ} 48.1^{\prime} \mathrm{N}$, $73^{\circ} 45.3^{\prime} \mathrm{E}$ ) is a roughly elliptic body, about $3 \times 2 \mathrm{~km}$ in size and $3 \mathrm{~km}^{3}$ in volume with steep, 250 to $700 \mathrm{~m}$ high edges and a relatively flat bottom [Strom, 2000; Strom, Groshev, 2009]. The second crater (Djuzumdy, $41^{\circ} 48.75^{\prime} \mathrm{N}$, $073^{\circ} 22.85^{\prime} \mathrm{E}$ ), about $1 \mathrm{x} 0.5 \mathrm{~km}$ and $200-300 \mathrm{~m}$ deep, has a roughly rhomboid form. Its volume is about $0.12 \mathrm{~km}^{3}$. It is located $28 \mathrm{~km}$ to the west of the Kyzylkul dam in the upper reaches of the Djuzumdybulak stream. The southern boundary of the Djuzumdy crater is an active fault that ruptured about 2000 years ago [Strom, 2000; Strom, Groshev, 2009]. These craters were compared to 
a similar crater formed during a M>8 earthquake in 1957 in Gobi Altai, Mongolia [Florensov, Solonenko, 1963] and accordingly attributed to a paleo-earthquake of $\mathrm{M}=7.5-8.0$ [Strom, 2009].

\section{CONCLUSION}

This work shows that the geographically unexpected Ms=7.3 Suusamyr earthquake of August 19, 1992 is not the strongest event that may occur in the area. Stronger seismic events took place not only in the western, but also in the southern parts of the Suusamyr earthquake source zone, namely within Minkush-Kokomeren transpressional zone, along which the Naryn River.

The Kambarata HPP-2 projects is already completed. Construction of the Kambarata Hydro Power Plant-1 has already started. Following the existing seismic zoning maps [Abdrakhmatov et al., 2012; Turdukulov, 1996], these two power plants are designed with account of risks of possible earthquakes with $<7.5$. Our study shows that magnitudes up to 8 should be expected. We hope that experts in seismic zoning and earthquake-resistant construction will revise and reassess their project to face the risk.

\section{8. ЛИТЕРАТУРA/REFERENCES}

Abdrakhmatov K.Ye., Djanuzakov K.D., Frolova A.F., Pogrebnoy V.N., 2012. The Map of Seismic Zoning of Kyrgyz Republic. Explanatory Note. Ilim, Bishkek, 51 c. (in Russian) [Абдрахматов К.Е., Джанузаков К.Д., Фролова А.Ф., Погребной В.Н. Карта сейсмического районирования территории Кыргызской Республики. Объяснительная записка. Бишкек: Илим, 2012. 51 с.].

Ainscoe E.A., Abdrakhmatov K.E., Baikulov S., Carr A.S, Elliott A.J., Grützner C., Walker R.T., 2019. Variability in surface rupture between successive earthquakes on the Suusamyr Fault, Kyrgyz Tien Shan: implications for palaeoseismology. Geophysical Journal International 216 (1), 703-725. https://doi.org/10.1093/gji/ggy457.

Angelier J., 1994. Fault slip analysis and paleostress reconstruction, In: P.L. Hancock (Ed.), Continental deformation. Pergamon Press Ltd, Oxford, p. 53-100.

Bachmanov D.M., Trifonov V.G., Mikolaichuk A.V., Vishnyakov F.A., Zarshchikov A.A., 2008. The Ming-Kush-Kökömeren zone of recent transpression in the Middle Tien Shan. Geotectonics 42 (3), 186-205. https://doi.org/10.1134/ s0016852108030035.

Bazhenov M.L., Burtman V.S., Dvorova A.V., 1999. Permian paleomagnetism of the Tien Shan fold belt, Central Asia: post-collisional rotations and deformation. Tectonophysics 312 (2-4), 303-329. https://doi.org/10.1016/S00 40-1951(99)00181-X.

Bazhenov M.L., Mikolaichuk A.V., 2004. Structural evolution of Central Asia to the North of Tibet: a synthesis of paleomagnetic and geological data. Geotectonics 38 (5), 379-393.

Bogachkin B.M., Korjenkov A.M., Mamyrov E., Nechaev Yu.V., Omuraliev M., Petrosyan A.E., Pletnev K.G., Rogozhin E.A., Charimov T.A., 1997. The structure of the 1992 Susamyr earthquake source based on its geological and
With a similar warning conclusion, attention should be drawn to the western part of the Minkush-Kokomeren transpressional zone that includes the Toktogul water reservoir, the largest in Central Asia with a volume of $19.5 \mathrm{~km}^{3}$ and an area of $284 \mathrm{~km}^{2}$ [Simpson, Negmatullaev, 1978]. Filling of the reservoir started in 1973. At that time, the geological study of the territory subject to flooding consisted only of geological mapping (scale 1:200000) and aeromagnetic studies (scale 1:100000). Deep structures hidden beneath the Cenozoic cover were ignored.

Our data showing that the Minkush-Kokomeren transpressional zone extends as far west as the Talas-Fergana Fault give grounds to conclude that the reservoir is a high-risk site that should be surveyed with geophysical sounding techniques (electric, magnetic, seismic), and activities aimed at mitigation of any catastrophic event should be properly planned.

\section{ACKNOWLEDGMENT}

We are grateful to Alexander Strom for a comprehensive discussion of the Inner Tienshan seismodislocations. We thank SNSF for financial support of this research (Project No IB7320-110694).

seismological manifestations. Izvestiya, Physics of the Solid Earth 33 (11), 867-882.

Burg J.-P., Célérier B., Chaudhry N.M., Ghazanfar M., Gnehm F., Schnellmann M., 2005. Fault analysis and paleostress evolution in large strain regions: methodological and geological discussion of the southeastern Himalayan fold-and-thrust belt in Pakistan. Journal of Asian Earth Sciences 24 (4), 445-467. https://doi.org/10.1016/j.jseaes. 2003.12.008.

Burg J.-P., Mikolaichuk A.V. (Eds), 2009. Digital Geological and Natural Hazard Maps of the Inner Tien-Shan (Kyrgyzstan). SNSF, Project No IB7320-110694. Available from: http://www.kyrgyzstan.ethz.ch.

Burtman V.S., Skobelev S.F., Molnar P., 1996. Late Cenozoic slip on the Talas-Fergana fault, the Tien Shan, Central Asia. Geological Society of America Bulletin 108 (8), 10041021. https://doi.org/10.1130/0016-7606(1996)108<10 04:LCSOTT>2.3.CO;2.

Célérier B., 2009. FSA: Fault Slip Analysis software. Available from: http://www.pages-perso-bernard-celerier.univmontp2.fr/software/dcmt/fsa/fsa.html.

Célérier B., Etchecopar A., Bergerat F., Vergely P., Arthaud F., Laurent $P$., 2012. Inferring stress from faulting: From early concepts to inverse methods. Tectonophysics 581, 206-219. https://doi.org/10.1016/j.tecto.2012.02.009.

Delvaux D., Abdrakhmatov K.E., Lemzin I.N., Strom A.L., 2001. Landslides and surface breaks of the 1911 Ms8.2 Kemin earthquake, Kyrgyzstan. Geologiya i Geofizika (Russian Geology and Geophysics) 42 (10), 1667-1677.

Djanuzakov K.D., Iliasov B.I., Knauf V.I., Korolyov V.G., Khristov E.V., Chediya O.K., 1980. Kyrgyz Republic. In: V.I. Bune, G.P Gorshkov (Eds.), Seismic zoning of the USSR territory. Nauka, Moscow, p. 183-194 (in Russian) [Джанузаков К.Д., Ильясов Б.И., Кнауф В.И., Королев В.Г., Христов Е.В., Чедия О.К. Киргизия // Сейсмическое районирование 
территории СССР / Ред. В.И. Бунэ, Г.П. Горшков. М.: Наука, 1980. C. 183-194].

Djanuzakov K.D., Iliasov B.I., Muraliev A.M., Yudakhin F.N., 1997. The August 19, 1992 Suusamyr earthquake. In: Earthquakes of Northern Eurasia in 1992. Geoinformmark, Moscow (in Russian) [Джанузаков К.Д., Ильясов Б.И., Муралиев А.М., Юдахин Ф.Н. Суусамырское землетрясение 19 августа 1992 года // Землетрясения Северной Евразии в 1992 году. М.: Геоинформмарк, 1997. С. 49-54].

Djanuzakov K.D., Omuraliev M., Omuralieva A., Iliasov B.I., Grebennikova V.V., 2003. Strong Earthquakes of Tienshan (within the Territory of Kyrgyzstan and Adjacent Areas of the Countries of Central Asia). Ilim, Bishkek, 216 p. (in Russian) [Джанузаков К.Д., Омуралиев М., Омуралиева А., Ильясов Б., Гребенникова В.В. Сильные землетрясения Тянь-Шаня (в пределах территории Кыргызстана и прилегающих районов стран Центральной Азии). Бишкек: Илим, 2003. 216 с.].

Florensov N.A., Solonenko V.P. (Eds), 1963. Gobi Altai Earthquake. Publishing House of the USSR Acad. Sci., Moscow, 391 p. (in Russian) [Гоби-Алтайское землетрясение/ Ред. Н.А. Флоренсов, В.П. Солоненко. М.: Изд-во АН СССР, 1963. 391 c.].

Ghose S., Mellors R.J., Korjenkov A.M., Hamburger M.W., Pavlis T.L., Pavlis G.L, Omuraliev M., Mamyrov E., Muraliev A.R., 1997. The Ms=7.3 1992 Suusamyr, Kyrgyzstan earthquake: 2. Aftershock focal mechanisms and surface deformation. Bulletin of the Seismological Society of America 87 (1), 23-38.

Havenith H.-B., Jongmans D., Abdrakhmatov $K$., Trefois $P$., Delvaux D., Torgoev I.A., 2000. Geophysical investigations of seismically induced surface effects: case study of a landslide in the Suusamyr Valley, Kyrgyzstan. Surveys in Geophysics 21 (4), 351-370. https://doi.org/10.1023/A:100 6788808145.

Kalmetieva Z.A., Mikolaichuk A.V., Moldobekov B.D., Meleshko A.V., Jantaev M.M., Zubovich A.V., 2009. The Atlas of Earthquakes in Kyrgyzstan. CAIAG, Bishkek, 75 p. Available from: http://www.caiag.kg/en/scientific-activity/comple ted-projects/eq-atlas.

Korjenkov A.M., 2006. Seismogeology of the Tien-Shan (within the Territory of Kyrgyzstan and Adjacent Areas). Ilim, Bishkek, 290 p. (in Russian) [Корженков A.M. Сейсмогеология Тянь-Шаня (в пределах территории Кыргызстана и прилегающих районов). Бишкек: Илим, 2006. 290 c.].

Korjenkov A.M., Bobrovskii A.V., Mamyrov E.M., 2010. Evidence for strong paleoearthquakes along the Talas-Fergana Fault near the Kok-Bel Pass, Kyrgyzstan. Geotectonics 44 (3), 262-270. https://doi.org/10.1134/S0016852 110030040.

Korjenkov A., Rust D., Tibaldi A., Abdieva S., 2012. Parameters of the strong paleoearthquakes along the TalasFergana Fault, the Kyrgyz Tien-Shan, In: S. D'amico (Ed.), Earthquake research and analysis - seismology, seismotectonics and earthquake geology. Tech Publishers, Rijeka, Croatia, p. 33-84.

Makarov V.I., Abdrakhmatov K.E., Thompson S.C., 2005. Recent earth crust motions according to the geological data.
In: N.P. Laverov (Ed.), Recent geodynamics of areas of intracontinental collision orogeny (Central Asia). Nauchny Mir, Moscow, p. 157-176 (in Russian) [Макаров В.И., Абдрахматов К.Е., Томпсон С. Современные движения земной коры по геологическим данным // Современная геодинамика областей внутриконтинентального коллизионного горообразования (Центральная Азия) / Ред. Н.П. Лаверов. М.: Научный мир, 2005. С. 157-176].

Mamyrov E.M., Korjenkov A.M., Orlova L.A., Pogrebnoy V.I., Rast D., Strom A.L., Fortuna A.B., Bobrovski A.B., Grebennikova V.V., Makhankova V.A., Nurmanbetov K., 2009. Geodynamics of Talas-Fergana fault in Tien Shan and Natural Disasters on the Central Asia territory. Arashan Publishing House, Bishkek, 230 p. (in Russian) [Мамыров Э.М., Корженков А.М., Орлова Л.А., Погребной В.Н., Раст Д., Стром А.Л., Фортуна А.Б., Бобровский А.Б., Гребенникова В.В., Маханькова В.А., Нурманбетов К. Геодинамика Талао-Ферганского разлома Тянь-Шаня и стихийные бедствия на территории Центральной Азии. Бишкек: Арашан, 2009. 230 с.].

McCalpin J.P. (Ed.), 1996. Paleoseismology (1st ed.). Academic Press, New York, 588 p.

McCalpin J.P. (Ed.), 2009. Paleoseismology (2nd ed.). Academic Press, San Diego, 647 p.

Mellors R.J., Vernon F.L., Pavlis G.L. Abers G.A. Hamburger M.W., Ghose S., Illiasov B., 1997. The Ms=7.3 1992 Suusamyr, Kyrgyzstan earthquake: 1 . Constraints on fault geometry and source parameters based on aftershocks and body wave modeling. Bulletin of the Seismological Society of America 87 (1), 11-22.

Mikolaichuk A.V., Satybekov M.B., Gordeev D.V., 2008. Structural position of intramountain basin of Central Tien-Shan. In: Geodynamics of intracontinental orogenes and geoenvironmental problems. Fourth International Symposium. Abstracts \& Papers (June 15-23, 2008). Bishkek, p. 70-74 (in Russian) [Миколайчук А.В., Сатыбеков М.Б., Гордеев Д.В. Формирование (кинематика и становление) внутригорных впадин Тянь-Шаня // Геодинамика внутриконтинентальных орогенов и геоэкологические проблемы: Тезисы Четвертого международного симпозиума (г. Бишкек, 15-23 июня 2008 г.). С. 70-74].

Morozov Yu.A., Leonov M.G., Alekseev D.V., 2014. Pullapart formation mechanism of Cenozoic basins in the Tien Shan and their transpressional evolution: Structural and experimental evidence. Geotectonics 48 (1), 24-53. https: / / doi.org/10.1134/s0016852114010051.

Rebetsky Yu.L., Sycheva N.A., Sychev V.N., Kuzikov S.I., Marinin A.V., 2016. The stress state of the northern Tien Shan crust based on the KNET seismic network data. Russian Geology and Geophysics 57 (3), 387-408. https://doi.org/ 10.1016/j.rgg.2016.03.003.

Sadybakasov I., 1990. Neotectonics of High Asia. Nauka, Moscow, 181 p. (in Russian) [Садыбакасов И. Неотектоника Высокой Азии. М.: Наука, 1990. 181 с.].

Selander J., Oskin M., Ormukov C., Abdrakhmatov K., 2012. Inherited strike-slip faults as an origin for basement-cored uplifts: Example of the Kungey and Zailiskey ranges, northern Tian Shan. Tectonics 31 (4), TC4026. https://doi.org/10. 1029/2011TC003002. 
Simpson D.W., Negmatullaev S.Kh., 1978. Induced seismicity studies in Soviet Central Asia. Earthquake Information Bulletin 10, 208-213.

Solonenko V.P., 1974. Seismogeology and problem of the earthquakes prediction. Geologiya i Geofizika (Soviet Geology and Geophysics) 15 (5), 158-178 (in Russian) [Солоненко В.П. Сейсмогеология и проблема предсказания землетрясений // Геология и геофизика. 1974. Т. 15. № 5. С. 168-178].

Strom A.L., 2000. Caldera-like collapses at the watersheds in the Central Tien Shan: their structure and possible mechanism. In: E. Bromhead, N. Dixon, M.-L. Ibsen (Eds), Landslides in research, theory and practice. Vol. 3. Thomas Telford, London, p. 1413-1418.

Strom A., 2009. Lessons learned from the Wenchuan earthquake: their application for the Tien Shan. In: Rock Characterization, Modelling and Engineering Design Methods. Proceedings of the ISRM International Symposium on Rock Mechanics SINOROCK2009. Hong Kong, on CD.

Strom A., 2010. Landslide dams in Central Asia Region. Journal of the Japan Landslide Society 47 (6), 309-324. https://doi.org/10.3313/jls.47.309.

Strom A., 2013. Geological prerequisites for landslide dams' disaster assessment and mitigation in Central Asia. In: F. Wang et al. (Eds), Progress of geo-disaster mitigation technology in Asia. Environmental science and engineering. Springer, Berlin, p. 17-53.
Strom A.L., Groshev M.E., 2009. Mysteries of rock massifs destruction. In: M. Abbie, J.S. Bedford (Eds.), Rock mechanics: new research. Nova Science Publishers, Hauppauge, p. 211-231.

Strom A.L., Stepanchikova P., 2008. Seismic triggering of large prehistoric rockslides: Pro and Con case studies. In: Proceedings of the International Conference on Management of Landslide Hazard in the Asia-Pacific Region (Satellite symposium of the First World Landslide Forum, Tokyo) (Sendai, 11th - 12th November 2008). Sendai, p. 202-211.

Su Zongzheng, Abdrakhmatov K.Ye, Cheng Xingyuan, Lemzin I.N., Yuan Zhengming, 1999. Seismotectonic and Seismic rupture of Suusamyr earthquake M 7.3, Kyrghyzstan, 1992. Earthquake Research in Shanxi 2, 1-8.

Trifonov B.G., Makarov V.I., Skobelev S.F., 1990. Talas-Fergana active right - lateral fault. Geotectonics 24 (5), 435-442.

Turdukulov A.T. (Ed.), 1996. The Map of Seismic Zoning of Kyrgyz Republic. Ilim, Bishkek (in Russian) [Карта сейсмического районирования Кыргызской Республики / Ред. А.Т. Турдукулов. Бишкек: Илим, 1996. 24 с.].

Twiss R.J., Moores E.M., 1992. Structural Geology. W.H. Freeman \& Company, New York, 532 p.

Twiss R.J., Unruh J.R., 1998. Analysis of fault slip inversions: do they constrain stress or strain rate? Journal of Geophysical Research: Solid Earth 103 (B6), 12205-12222. https://doi.org/10.1029/98JB00612.

Yeats R.S., Sieh K., Allen C.R., 1997. The Geology of Earthquakes. Oxford University Press, New York, 568 p.

\author{
ALEXANDER V. MIKOLAICHUK \\ Candidate of Geology and Mineralogy, Senior Researcher \\ Institute of Geology of NAS \\ 30 Erkindyk Blvd, Bishkek 720481, Kyrgyzstan \\ e-mail: alexander@mikolaichuk.com \\ ORCID: 0000-0002-0247-1856
}

\section{ZOYA A. KALMETEVA}

Candidate of Physical and Mathematical sciences, Senior Researcher

Central-Asian Institute for Applied Geosciences

73/2 Timur Frunze Rd, Bishkek 720027, Kyrgyzstan

e-mail: z.kalmetyeva@caiag.kg

ORCID: 0000-0001-5172-3741

\section{JEAN-PIERRE BURG}

Doctor, Full Professor of Geology

ETH Zurich Earth Sciences

5 Sonneggstrasse, Zurich CH-8092, Switzerland

e-mail: jean-pierre.burg@erdw.ethz.ch

ORCID: 0000-0002-4927-4729

\section{АЛЕКСАНДР ВЛАДИМИРОВИЧ МИКОЛАЙЧУК}

канд. геол.-мин. наук, с.н.с.

Институт геологии НАН

720481, г. Бишкек, бул. Эркиндик, 30, Кыргызстан

\section{ЗОЯ АРСЛАНОВНА КАЛЬМЕТЬЕВА}

канд. физ.-мат. наук, с.н.с.

Центрально-Азиатский институт прикладных исследований Земли

720027, г. Бишкек, ул. Тимура Фрунзе, 73/2, Кыргызстан

\section{ЖАН-ПЬЕР БУРГ}

докт., профессор геологии

Департамент наук о Земле, Высшая техническая школа

CH-8092, г. Цюрих, Зоннегштрассе, 5, Швейцария 


\section{DAVID FOSSATI}

Geological Engineer

Marti Tunnelbau AG

21 Seedorffeldstrasse, Moosseedorf 3302, Switzerland e-mail: dfoss81@hotmail.com

ORCID: 0000-0003-3995-6336

\section{DMITRY V. GORDEEV}

Post-graduate Student Institute of Geology of NAS

30 Erkindyk Blvd, Bishkek 720481, Kyrgyzstan

e-mail: d.gordeev56@outlook.com

ORCID: 0000-0001-8287-1018

\section{ДЭВИД ФОССАТИ}

инженер

Компания «Marti Tunnelbau AG»

3302, г. Мосзеедорф, Зеедорфельдштрассе, 21, Швейцария

\section{ДМИТРИЙ ВАЛЕНТИНОВИЧ ГОРДЕЕВ}

аспирант

Институт геологии НАН

720481, г. Бишкек, бул. Эркиндик, 30, Кыргызстан 